\title{
Introduction to the IJELL Special Series of Chais Conference 2016 Best Papers
}

\author{
Nitza Geri, Ina Blau, Avner Caspi, Yoram M. Kalman, \\ Vered Silber-Varod, and Yoram Eshet-Alkalai \\ The Open University of Israel, Raanana, Israel
}

nitzage@openu.ac.il; Inabl@openu.ac.il; avnerca@openu.ac.il; yoramka@openu.ac.il; vereds@openu.ac.il; yorames@openu.ac.il

\section{Abstract}

This preface presents the papers included in the eighth issue of the Interdisciplinary Journal of eSkills and Lifelong Learning (IJELL) special series of selected Chais Conference best papers. The Chais Conference for the Study of Innovation and Learning Technologies: Learning in the Technological Era, is organized annually by the Research Center for Innovation in Learning Technologies, The Open University of Israel. The $11^{\text {th }}$ Chais Conference was held at The Open University of Israel, Raanana, Israel, on February 16-17, 2016.

Keywords: learning technologies, e-learning, technology integration in education, diffusion of innovation, human-computer interaction.

\section{Introduction}

"Learning in the Technological Era" is a series of annual national research conferences on innovation and learning technologies, initiated in 2006 by the Research Center for Innovation in Learning Technologies (formerly, the Chais Research Center), The Open University of Israel. The purpose of the Chais conference is to promote the community of Israeli researchers in the field of learning technologies and the positioning of the Open University of Israel as a leading organization in the study and implementation of learning technologies. The eleventh Chais Conference for the Study of Innovation and Learning Technologies: Learning in the Technological Era, was held at The Open University of Israel, Raanana, Israel, on February 16-17, 2016.

The special series of selected Chais conference best papers is intended to expand the international impact of the conference by providing enhanced, extended versions of its finest papers to a global audience. The Informing Science Institute (ISI) enables this endeavor by publishing this special series in the Interdisciplinary Journal of e-Skills and Lifelong Learning (IJELL, formerly Inter-

(CC BY-NC 4.0) This article is licensed to you under a Creative Commons Attribution-

NonCommercial 4.0 International License. When you copy and redistribute this paper in full or in part, you need to provide proper attribution to it to ensure that others can later locate this work (and to ensure that others do not accuse you of plagiarism). You may (and we encourage you to) adapt, remix, transform, and build upon the material for any non-commercial purposes. This license does not permit you to use this material for commercial purposes. disciplinary Journal of E-Learning and Learning Objects (IJELLO)).

In 2015, we celebrated a decade of Chais conferences. Last year's preface, entitled "A decade of Chais conferences: Introduction to the IJELL special series of Chais conference 2015 best papers" (Geri, Blau, Caspi, Kalman, Silber-Varod, \& EshetAlkalai, 2015), describes the mission and activities of the Research Center for Innovation in Learning Technologies. It explains its synergies with the in- 
forming science transdiscipline (Cohen, 1999, 2009; Cohen \& Lloyd, 2014), the Informing Science Institute, and IJELL. Geri et al. (2015) also summarize the objectives and themes of the first ten years of the Chais conferences, as well as the first seven issues of the IJELL special series of selected Chais Conference best papers.

This preface launches the next decade of Chais conferences and presents the papers included in the eighth issue of the IJELL special series of selected Chais Conference best papers. This year, 107 papers were submitted for presentation at the eleventh Chais conference. Following a doubleblind peer-review process, 39 papers and 39 posters were accepted for presentation at the conference and were included in the proceedings volume of the conference (Eshet-Alkalai, Blau, Caspi, Geri, Kalman, \& Silber-Varod, 2016). The Best Student Paper Award, awarded for the fifth time this year, considered 23 student-based research papers accepted for presentation at the Chais conference 2016. Of these, extended versions of five papers out of the seven finalists for the Award are included in this IJELL special series.

\section{Chais Conference 2016 Best Papers}

The eighth selection of IJELL Special Series of Chais Conference Best Papers includes eight of the most outstanding Chais conference 2016 papers that have been expanded and edited for publication in IJELL and undergone a full review process by IJELL's Editors and reviewers.

The first paper by Tal Berger-Tikochinski, Michal Zion, and Ornit Spektor-Levy, "Up and down: Trends in students' perceptions about learning in a 1:1 laptop model - A longitudinal study", was the winner of the best student (Tal Berger-Tikochinski) paper award of the Chais conference 2016. Their five-year study, which involved 770 junior high school students, indicated that the level of positive attitudes towards learning with laptops declined over time. However, the attitudes of students who started the program in a later year were more positive than those who began earlier. Longitudinal, multi-year studies are rare in our field, and Berger-Tikochinski et al.'s study provides insights that may support future implementations of laptops, and represents a novel approach for studying technology integration in education.

The next paper, by Adi Friedman, Ina Blau, and Yoram Eshet-Alkalai, "Cheating and feeling honest: Committing and punishing analog versus digital academic dishonesty behaviors in higher education", was a finalist for the best student (Adi Friedman) paper award of the Chais conference 2016. This innovative paper examined the effect of technology use in the context of academic dishonesty. The findings were based on a detailed analysis of 315 protocols of a Disciplinary Committee and revealed intriguing insights on the perceptions of both the cheating students and the members of the Disciplinary Committee.

Ruti Gafni and Idan Nagar's paper, "CAPTCHA: Impact on user experience of users with learning disabilities", was also a finalist for the best student (Idan Nagar) paper award of the Chais conference 2016. The paper addressed the dilemma of cyber security between accessibility and security. Gafni and Nagar examined how five different sorts of CAPTCHA tests affect users with and without learning disabilities. Their findings may help develop CAPTCHA solutions, which are friendlier to humans, do not discriminate against users with learning disabilities, and are still able to detect software attempts to access a website.

Social activities are prevalent online. Yet, it is a challenge to design effective online environments that encourage certain social processes in pedagogical contexts. The design study by Noa Shapira, Hagai Kupermintz, and Yael Kali, entitled "Design principles for promoting intergroup empathy in online environments", was another finalist for the best student (Noa Shapira) paper award of the Chais conference 2016. The authors examined an online community of practice within a professional development program of Civics teachers, which was aimed at promoting empathy among diverse groups. The reasoning behind the program that sponsored the community 
was that teachers should feel empathy before supporting their students in the process of becoming empathic and that, if online activities are properly designed, empathic processes can occur online. The authors discuss their promising findings and recommend design principles that were found effective in promoting empathy.

Simona Holstein and Anat Cohen's study, "The characteristics of successful MOOCs in Software, Science, and Management fields according to students' perception", was another finalist for the best student (Simona Holstein) paper award of the Chais conference 2016. Massive Open Online Courses (MOOCs) are proliferating in recent years. Holstein and Cohen analyzed thousands of student reviews of xMOOCs, which are instructor-driven online learning environments. The analyses included both quantitative and qualitative methods and found 14 characteristics that contribute to xMOOCs success. Their study emphasizes the importance of listening to the voices of students in order to enable better adaptation of MOOCs.

The paper "Can designing self-representations through creative computing promote an incremental view of intelligence and enhance creativity among at-risk youth?" by Ina Blau and Nurit Benolol, examines the potential of creative computing to increase the self-esteem of youth. Blau and Benolol conducted an experiment that included an intervention, with 117 youth, half of whom were classified as at-risk youth. All the participants received basic training for Scratch programming application and designed artifacts that represented themselves five years in the future. Blau and Benolol's results demonstrate the potential of creative computing combined with an Implicit Theories of Intelligence (ITI) intervention for developing creativity and improving well-being, particularly among at-risk youth.

The next paper, "Perceptions of teacher educators regarding ICT implementation in Israeli colleges of education", by Orit Avidov-Ungar and Alona Forkosh-Baruch, investigated facilitating and hindering factors of Information and Communication Technologies (ICT) implementation in teacher education institutes. This qualitative study addressed three levels of measuring ICT integration: the teacher educators, the students, and the organization (i.e., the college). Data were collected twice, within two-year intervals, allowing the authors to identify trends. The main hindering factors were lack of resources, particularly time and infrastructure, which suggests that policy issues, at both the college level and the national level, have major effect on the success of ICT implementation in education.

The closing paper of this selection is "Analyzing the discourse of Chais Conferences for the Study of Innovation and Learning Technologies via a data-driven approach", by Vered SilberVarod, Yoram Eshet-Alkalai, and Nitza Geri. The study examined changes over time in the research of learning technologies, as reflected in the corpus of articles published during 2006-2014 in the proceedings of Chais Conferences. The interesting finding, which is also evident in the papers included in the present selection, is the focus of the Chais conferences on the pedagogical aspects of learning technologies, rather than the technological ones.

These eight multifaceted papers represent some of the main themes discussed at the Chais conference 2016. Other main themes presented at the conference, which are not represented in this special selection, include social networks, reading and writing in the digital era, technology integration in science teaching, and assistive technologies for people with special needs.

\section{Conclusion and Acknowledgements}

This eighth issue of IJELL's special selection of the Chais conference best papers continues the discussion of current research in learning technologies. The common thread of the research published in the series is the focus on the pedagogical, rather than the technological aspects of learning technologies. The next Chais conference for the study of innovation and learning technologies is scheduled for February 14-15, 2017, at the Open University of Israel campus in Raanana, Isra- 
el. We look forward to continuing this fruitful discussion at the conference and the following IJELL issue of the best papers series.

We would like to express our deep gratitude to Janice Whatley, the Editor of the IJELL selection of Chais conference 2016 best papers, for her constructive guidance of the authors and for leading this editorial effort. We thank Gila Kurtz, the former Editor-in-Chief of IJELL, for her enthusiastic support of this endeavor. Special thanks to Eli Cohen and Betty Boyd of the Informing Science Institute for enabling the production of this special series, and to Betty for her publishing work. We thank IJELL's reviewers for their feedback to the authors and praise the contributing authors for their excellent work.

Last, we would like to thank the community of Israeli researchers and practitioners of learning technologies, for their continuing participation in Chais conferences and their collaboration in advancing this important research field.

\section{References}

Cohen, E. (1999). Reconceptualizing information systems as a field of the transdiscipline informing science: From ugly duckling to swan, Journal of Computing and Information Technology, 7(3), 213-219.

Cohen, E. (2009). A philosophy of informing science. Informing Science: the International Journal of an Emerging Transdiscipline, 12, 1-15. Retrieved from https://www.informingscience.org/Publications/425

Cohen, E., \& Lloyd, S. (2014). Disciplinary evolution and the rise of the transdiscipline. Informing Science: the International Journal of an Emerging Transdiscipline, 17,189-215. Retrieved from https://www.informingscience.org/Publications/2045

Eshet-Alkalai, Y., Blau, I., Caspi, A., Geri, N., Kalman, Y. M., \& Silber-Varod, V. (Eds.). (2016). Proceedings of the 11th Chais Conference for the Study of Innovation and Learning Technologies: Learning in the technological era. Raanana: The Open University of Israel [partly Hebrew]. Retrieved from http://www.openu.ac.il/innovation/chais2016/2016-book.pdf

Geri, N, Blau, I., Caspi, A., Kalman, Y. M., Silber-Varod, V., \& Eshet-Alkalai, Y. (2015). A decade of Chais conferences: Introduction to the IJELL special series of Chais conference 2015 best papers. Interdisciplinary Journal of e-Skills and Life Long Learning, 12, 149-157. Retrieved from https://www.informingscience.org/Publications/2331

\section{Biographies}

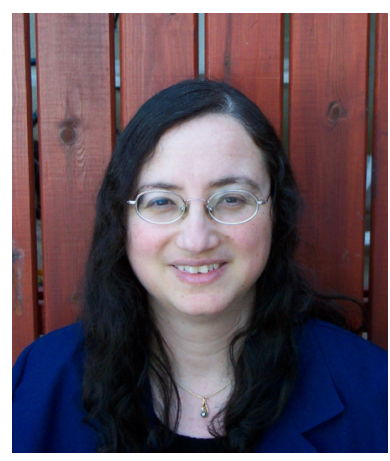

Nitza Geri is an Associate Professor at the Open University of Israel, Department of Management and Economics, and Head of the Research Center for Innovation in Learning Technologies. She holds a B.A. in Accounting and Economics, an M.Sc. in Management Sciences, and a Ph.D. in Technology and Information Systems Management from TelAviv University. Nitza is a CPA (Israel) and prior to her academic career she had over 12 years of business experience. Her research interests and publications focus on various aspects of the value of information and knowledge, as well as adoption, implementation, and continued use of information systems, including strategic information systems, ebusiness, information economics, attention economy, knowledge management, value creation and the Theory of Constraints, managerial aspects of e-learning systems. Personal site: http://www.openu.ac.il/Personal_sites/nitza-geri.html 


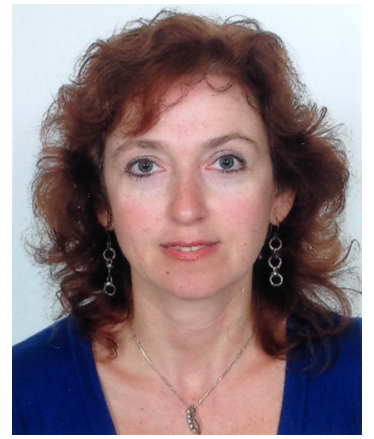

Ina Blau is a Senior Lecturer in the Department of Education and Psychology at the Open University of Israel. She holds a Ph.D. in ELearning and Cyber-Psychology from the University of Haifa, Israel. Her research interests include social aspects of e-communication and eleadership, integration of innovative technologies in K-12, academia and organizations, mobile learning and interaction, digital literacy skills, online privacy in social networking, and psychological ownership in ecollaboration. Personal site: http://www.openu.ac.il/Personal_sites/ina-blau/

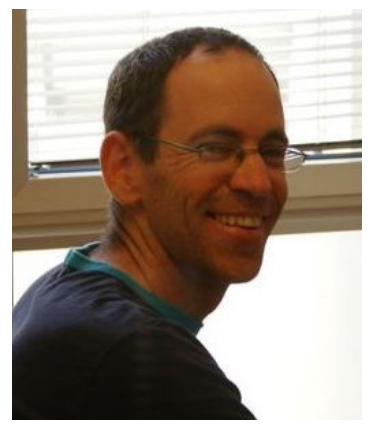

Avner Caspi is a Senior Lecturer at the Open University of Israel, Department of Education \& Psychology. He holds a B.A. in Behavioral Sciences (Tel-Aviv Yaffo Academic College), and Ph.D. in Cognitive Psychology (Tel Aviv University). His major research and publications interests focus on social aspects of communication technologies, mainly in the area of learning and instruction. Personal site:

http://www.openu.ac.i1/Personal_sites/avner-caspi.html

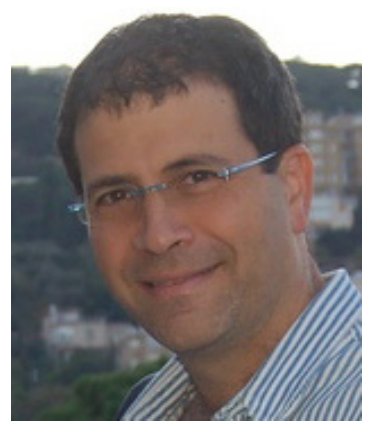

Yoram M Kalman is a Senior Lecturer at The Open University of Israel's department of Management and Economics. He studies the impact of digital technologies on people, organizations and society. His research focuses on aspects of computer-mediated communication (CMC), human-computer interaction (HCI), information systems (IS) and computer supported cooperative work (CSCW). Yoram led the Open University's massive online open courses (MOOC) initiative, and was the founding CEO of the Open University's subsidiary, Online Academe Ltd. Personal site: http://www.kalmans.com.

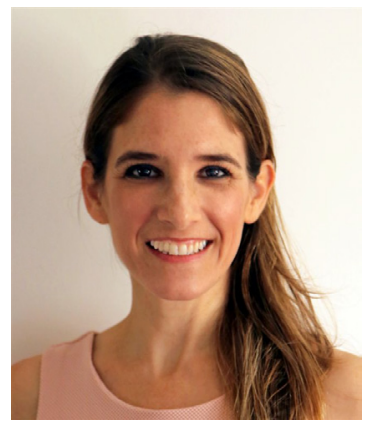

Vered Silber-Varod is a Research Fellow at The Research Center for Innovation in Learning Technologies, The Open University of Israel, Ra'anana. She received the B.A. in Political Science and French language and literature studies from the Hebrew University of Jerusalem, a M.A. degree with Magna Com Lauda in Hebrew language studies at the department of Hebrew and Semitic languages from Tel Aviv University and the Ph.D. degree from Tel Aviv University. She teaches Modern Hebrew phonology. Previously,, she was a researcher at the ACLP Afeka Center for Language Processing, Afeka College of Engineering. Her research interests include speech prosody, acoustic phonetics, speech technologies, and quantitative analysis of written and spoken texts. Personal site: http://www.openu.ac.il/en/personalsites/VeredSilberVarod.aspx 


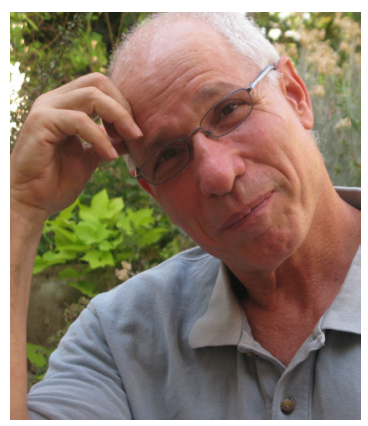

Yoram Eshet-Alkalay is a Professor at the Open University of Israel, Department of Education \& Psychology. He is Head of the M.A. program in educational technology, and the former Head of the Research Center for Innovation in Learning Technologies in the Open University. He holds a B.A. in Archeology (Hebrew University), M.Sc. in Geology (Hebrew University) and Ph.D. in Earth \& Environmental Sciences (City University of NY). For a decade, he was the Head of the Instructional Design Program in the Tel Hai Academic College, and a senior researcher in the Geological Survey of Israel. He has more than 15 years of experience in developing technology-based instructional solutions for educational systems in Israel and the USA. In this capacity, he was involved in the design of hundreds of simulations, data-bases, tutorials and large-scale curriculum integration projects. His major research and publications interests focus on cognitive aspects of working with digital technologies, digital literacy, digital games, digital dishonesty, and design principles of computer-based learning environments. Personal site: http://www.openu.ac.il/Personal_sites/yoram-eshet.html 